University of Nebraska - Lincoln

DigitalCommons@University of Nebraska - Lincoln

Library Philosophy and Practice (e-journal)

Libraries at University of Nebraska-Lincoln

January 2014

\title{
A Scientometric Analysis of Global Forensic Science Research Publications
}

John Jeyasekar Jesubright

Forensic Sciences Department, Chennai, India, trijays@gmail.com

Saravanan P Dr.

Lakshmipuram College of Arts \& Sciences, sara_nps@yahoo.co.in

Follow this and additional works at: https://digitalcommons.unl.edu/libphilprac

Part of the Library and Information Science Commons

Jesubright, John Jeyasekar and P, Saravanan Dr., "A Scientometric Analysis of Global Forensic Science Research Publications" (2014). Library Philosophy and Practice (e-journal). 1024.

https://digitalcommons.unl.edu/libphilprac/1024 


\title{
A SCIENTOMETRIC ANALYSIS OF GLOBAL FORENSIC SCIENCE RESEARCH PUBLICATIONS
}

\author{
J. John Jeyasekar \\ Librarian \\ Forensic Sciences Department, Mylapore, Chennai -4 \\ (Part-Time Research Scholar, Manonmaniam Sundaranar University, Tirunelveli) \\ Mobile: 09444525024 E-mail: trijays@gmail.com \\ and \\ Dr. P. Saravanan \\ Librarian
}

Lekshmipuram College of Arts and Science, Neyyoor, Kanyakumari District

Mobile: 09442711097 E-mail: sara nps@yahoo.co.in 


\section{A SCIENTOMETRIC ANALYSIS OF GLOBAL FORENSIC SCIENCE RESEARCH PUBLICATIONS}

\section{ABSTRACT}

A scientometric study of forensic science literature from the year 1975 to 2011 is carried out to find out the growth in forensic science literature, authors' productivity, the top ranking source journal and the country-wise productivity. The data for the study is obtained from the SCOPUS database. The 13626 number of results retrieved are analysed using excel worksheets. Google Scholar database is used as a data source for citation analysis of the authors who are found highly productive in the SCOPUS data. Publish or Perish (PoP) software is used for the citation analysis. It is found forensic science literature has seen an explosive growth during the period of study. Bruce Budowle is the author who has contributed the highest number of articles. The three journals, Journal of Forensic Sciences, Forensic Science International and Science \& Justice contribute almost half of the total forensic science literature. The United States of America contribute 30\% forensic science literature. FBI Laboratory is the only forensic science laboratory in the top ten affiliating institutions.

KEYWORDS: Scientometrics, Forensic Science, Research Productivity, Authorship Productivity, SCOPUS, Google Scholar, Publish or Perish (PoP)

\section{INTRODUCTION}

Forensic science refers to the application of principles and methods of specialized scientific and technical knowledge to criminal and civil legal questions and presenting the finding in an unbiased and objective way in courts of law. According to Saferstein (2001) "Forensic science is the application of science to those criminal and civil laws that are enforced by police agencies in a criminal justice system." Thus forensic science is related to the police agencies and to the judiciary.

Forensic sciences include, but are not limited to pathology, psychiatry, psychology, odontology, toxicology, molecular biology, entomology. A forensic scientist must be skilled in applying the principles 
and techniques of the physical and natural science to the analysis of the many types of evidence that may be recovered during crime investigation. Due to the interdisciplinary nature of the field, forensic literature are not limited to core forensic science journal but also can be found in interrelated disciplines of anthropology, chemistry, engineering, entomology, dentistry and physics, among others.

\section{SCIENTOMETRICS}

The field of Library and Information Science (LIS) has developed several quantitative methods to study the various aspects of subjects. The metrics of LIS are increasing day by day starting from Librametrics, Bibliometrics, Scientometrics, Informetrics, Webometrics, Netometrics to Cybermetrics.

The origin of the term scientometrics goes back to the year 1969, when two Russian scientists Nalimov and Mulechenko coined the Russian term naukometriya the Russian equivalent of scientometrics (Nalimov and Mulechenko, 1969). However, the advent of scientometrics as a discipline was in 1978, when the journal Scientometrics was founded by Tibor Braun in 1978. Scientometrics defines its content as "Scientometrics includes all quantitative aspects of the science of science, communication in science, and science policy." (Wilson, 1999)

The focus of scientometrics is the measurement of science and is therefore concerned with the growth, structure, interrelationship and productivity of scientific disciplines. Tague-Sutcliffe defines "Scientometrics is the study of the quantitative aspects of science as a discipline or economic activity. It is part of the sociology of science and has application to science policy-making. It involves quantitative studies of scientific activities, including, among others, publication, and so overlaps bibliometrics to some extent." (Tague-Sutcliffe, 1992)

\section{NEED AND SIGNIFICANCE OF THE STUDY}

Scientometric studies have increasingly been used over the last few years. These studies are useful to understand the evolution of literature or trends in particular fields or within a geographical area. 
However, in forensic science, scientometrics have barely been used. Alan Wayne Jones is the only author to have worked on bibliometric analysis of forensic science literature. His interesting work is mainly focused on most highly cited articles, most prolific authors and impact factors. (Sauvageau, Desnoyers and Godin, 2009)

\section{REVIEW OF LITERATURE}

Jones (2003) reviewed the impact factors of forensic science and toxicology journals and opined that the impact factors of these journals are low because the visibility and size of the circulation of these journals are low. During 2005, Jones identified with the help of Web of Science (WoS) the most highly cited papers published in the Journal of Forensic Sciences between 1956 and 2005. The most highly cited paper was by Kasai, Nakamura and White concerning DNA Profiling. Again Jones (2007) analysed the forensic science journals, their development and distribution and their current status as reflected in the journal impact factor. He concluded that the relatively low impact factors of forensic science journals are due to the small size of the field, fewer active researchers and less pressure to publish.

Sauvageau, Desnoyers and Godin (2009) studied the evolution of forensic science literature in two North American journals from 1980 to 2005 and found that forensic science literature in anthropology and DNA have increased significantly, while the contribution of questioned documents and ballistics have decreased. They also found out that the number of articles per year and the average numbers of authors per article have both increased almost two fold.

Jeyasekar and Saravanan (2012) conducted a scientometric study of forensic science to analyse the growth in literature, authorship productivity, the high ranking institution and country. It was found that the forensic science literature doubled between 2001 and 2011. In the same year, Jeyasekar and Saravanan carried out a scientometric analysis of the Indian forensic science literature for the period 2004 to 2011 using the Indian Citation Index (ICI) database. The study revealed that the forensic science 
publications are found not only in the core journals but also found scattered among journals of allied fields. The All India Institute of Medical Sciences (AIIMS) is the top contributor of Indian forensic science literature. Jeyasekar and Saravanan (2013) carried out a bibliometric study of the Journal of Forensic Sciences and found that there is an increase in publications on digital and multimedia aspects of forensic science and the literature related to application of DNA technology in forensic science is also increasing. The mean degree of authorship collaboration is 0.91 .

\section{OBJECTIVES OF THE STUDY}

The objectives of the present study are as follows:

1. To study the growth of forensic science research literature.

2. To identify the authors' productivity.

3. To examine the source journals which contribute the forensic science literature.

4. To analyse the country-wise and the affiliating institution-wise contribution.

5. To identify the most cited research article.

\section{METHODOLOGY}

The data for the study period 1975 to 2011 is retrieved from the SCOPUS database using "forensic science" as the keyword. SCOPUS is an international multidisciplinary database indexing over 15,000 international peer reviewed journals in Science and Technology, besides more than 500 international conference and seminar proceedings. So far SCOPUS is the single largest international multidisciplinary database in the world. The 13626 number of results retrieved are analysed using excel worksheets. Google Scholar database is used as a data source for citation analysis of the authors who are found to be highly productive in the SCOPUS data. Publish or Perish software is used for this citation analysis.

\section{RESULTS AND DISCUSSIONS}




\section{Growth of Literature}

The number of articles, the percentage and cumulative growth for the period from 1975 to 2011 are given in Table 1. Forensic science literature has grown exponentially during this period. This finding confirms to the Price's (1963) statement that "Once in ten years the number of articles in a field (particularly in science) doubles". The growth pattern is illustrated in Fig. 1. The cumulative growth is graphically illustrated in Fig. 2.

Table 1: Growth of literature

\begin{tabular}{|c|c|c|c|}
\hline Year & No. of articles & $\begin{array}{l}\text { Percentage of } \\
13626\end{array}$ & $\begin{array}{l}\text { Cumulative } \\
\text { Growth }\end{array}$ \\
\hline 1975 & 89 & 0.65 & 89 \\
\hline 1976 & 52 & 0.38 & 141 \\
\hline 1977 & 60 & 0.44 & 201 \\
\hline 1978 & 51 & 0.37 & 252 \\
\hline 1979 & 49 & 0.36 & 301 \\
\hline 1980 & 61 & 0.45 & 362 \\
\hline 1981 & 63 & 0.46 & 425 \\
\hline 1982 & 78 & 0.57 & 503 \\
\hline 1983 & 98 & 0.72 & 601 \\
\hline 1984 & 87 & 0.64 & 688 \\
\hline 1985 & 76 & 0.56 & 764 \\
\hline 1986 & 65 & 0.48 & 829 \\
\hline 1987 & 57 & 0.42 & 886 \\
\hline 1988 & 79 & 0.58 & 965 \\
\hline 1989 & 88 & 0.65 & 1053 \\
\hline 1990 & 166 & 1.22 & 1219 \\
\hline 1991 & 156 & 1.14 & 1375 \\
\hline 1992 & 180 & 1.32 & 1555 \\
\hline 1993 & 193 & 1.42 & 1748 \\
\hline 1994 & 195 & 1.43 & 1943 \\
\hline 1995 & 192 & 1.41 & 2135 \\
\hline 1996 & 359 & 2.63 & 2494 \\
\hline 1997 & 392 & 2.88 & 2886 \\
\hline 1998 & 450 & 3.30 & 3336 \\
\hline 1999 & 493 & 3.62 & 3829 \\
\hline 2000 & 578 & 4.24 & 4407 \\
\hline 2001 & 757 & 5.56 & 5164 \\
\hline 2002 & 765 & 5.61 & 5929 \\
\hline 2003 & 769 & 5.64 & 6698 \\
\hline
\end{tabular}




\begin{tabular}{|l|l|l|l|}
\hline 2004 & 660 & 4.84 & 7358 \\
\hline 2005 & 737 & 5.41 & 8095 \\
\hline 2006 & 792 & 5.81 & 8887 \\
\hline 2007 & 787 & 5.78 & 9674 \\
\hline 2008 & 818 & 6.00 & 10492 \\
\hline 2009 & 951 & 6.98 & 11443 \\
\hline 2010 & 1008 & 7.40 & 12451 \\
\hline 2011 & 1175 & 8.62 & 13626 \\
\hline Total & 13626 & 99.99 & 13626 \\
\hline
\end{tabular}

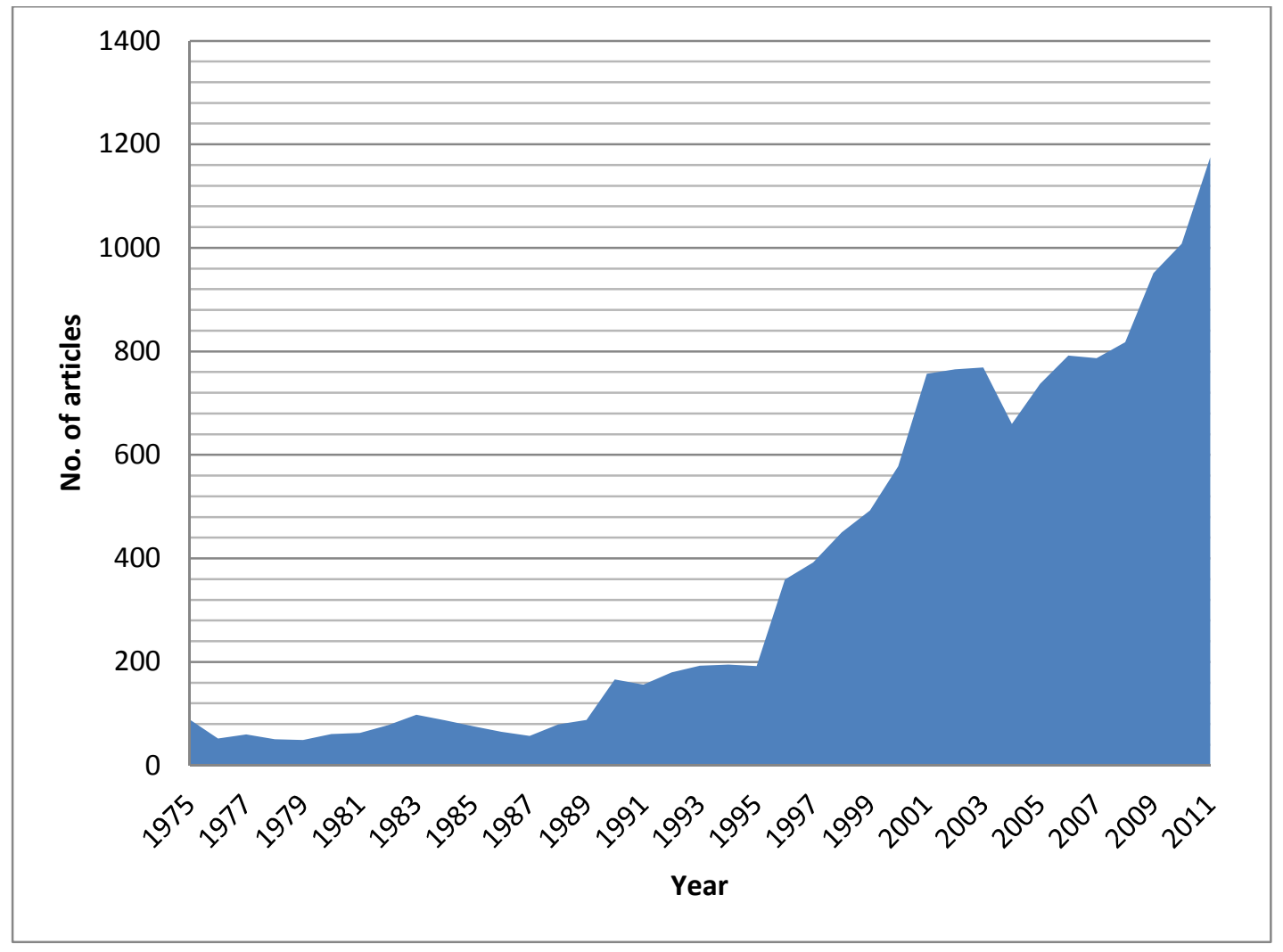

Fig. 1 Growth pattern 


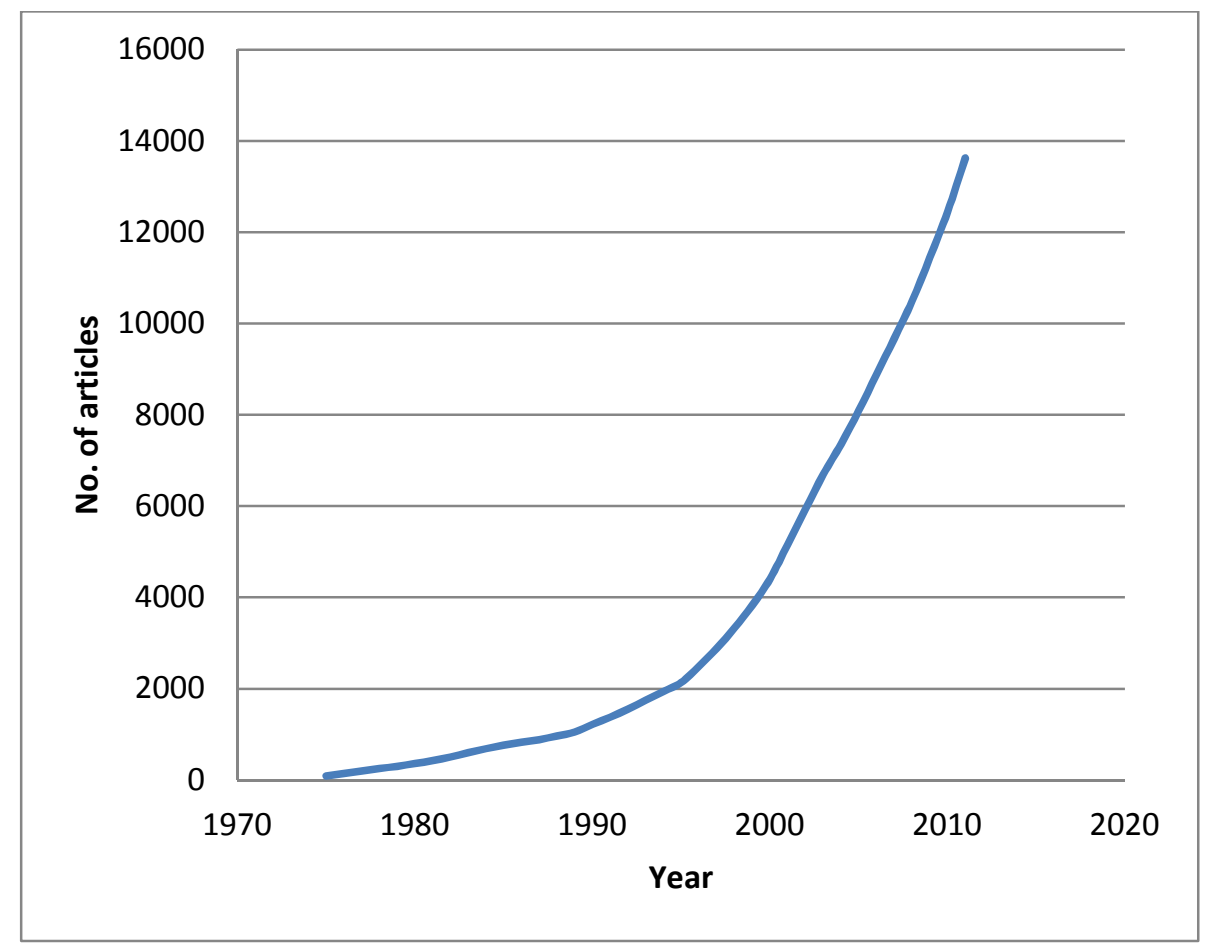

Fig. 2: Cumulative Growth

\section{Authors' Productivity}

Authors' productivity is studied based on their contributions in the field. If the authors have equal number of contributions then the same rank is assigned to them. The details are provided in Table 2.

Table 2: Top contributors

\begin{tabular}{|l|l|r|}
\hline Rank & Author & Contribution \\
\hline 1 & Budowle, B. & 166 \\
\hline 2 & Hou, Y.P. & 79 \\
\hline 3 & Byard, R.W. & 74 \\
\hline 4 & Wu, J. & 64 \\
\hline 5 & Roux, C. & 55 \\
\hline 5 & Buckleton, J.S. & 55 \\
\hline 6 & Li, Y.B. & 54 \\
\hline 7 & Thali, M.J. & 53 \\
\hline 8 & Robertson, J. & 49 \\
\hline 8 & Madea, B. & 49 \\
\hline 9 & Parson, W. & 48 \\
\hline 10 & Carracedo, A. & 46 \\
\hline
\end{tabular}


Bruce Budowle is the top contributor with 166 articles to his credit. Six of these twelve authors (50\%) are from the field of forensic genetics/DNA. DNA Fingerprinting is one of the recently developing fields of study in forensic science. This is in conformity with the findings of Sauvageau (2009) and also with the findings of Jeyasekar and Saravanan (2013) discussed in the review of literature that the literature related to DNA Technology.

\section{Comparison of Authors' Productivity Based on SCOPUS and Google Scholar}

The highly productive authors obtained from SCOPUS database is further compared with Google Scholar. The chart showing the numbers of papers of these authors are given in Fig. 3. It is very clear that the number of papers is substantially high for all the authors except Y.P.Hou in Google Scholar. This is mainly because Google Scholar covers journals and web resources that are not included in SCOPUS.

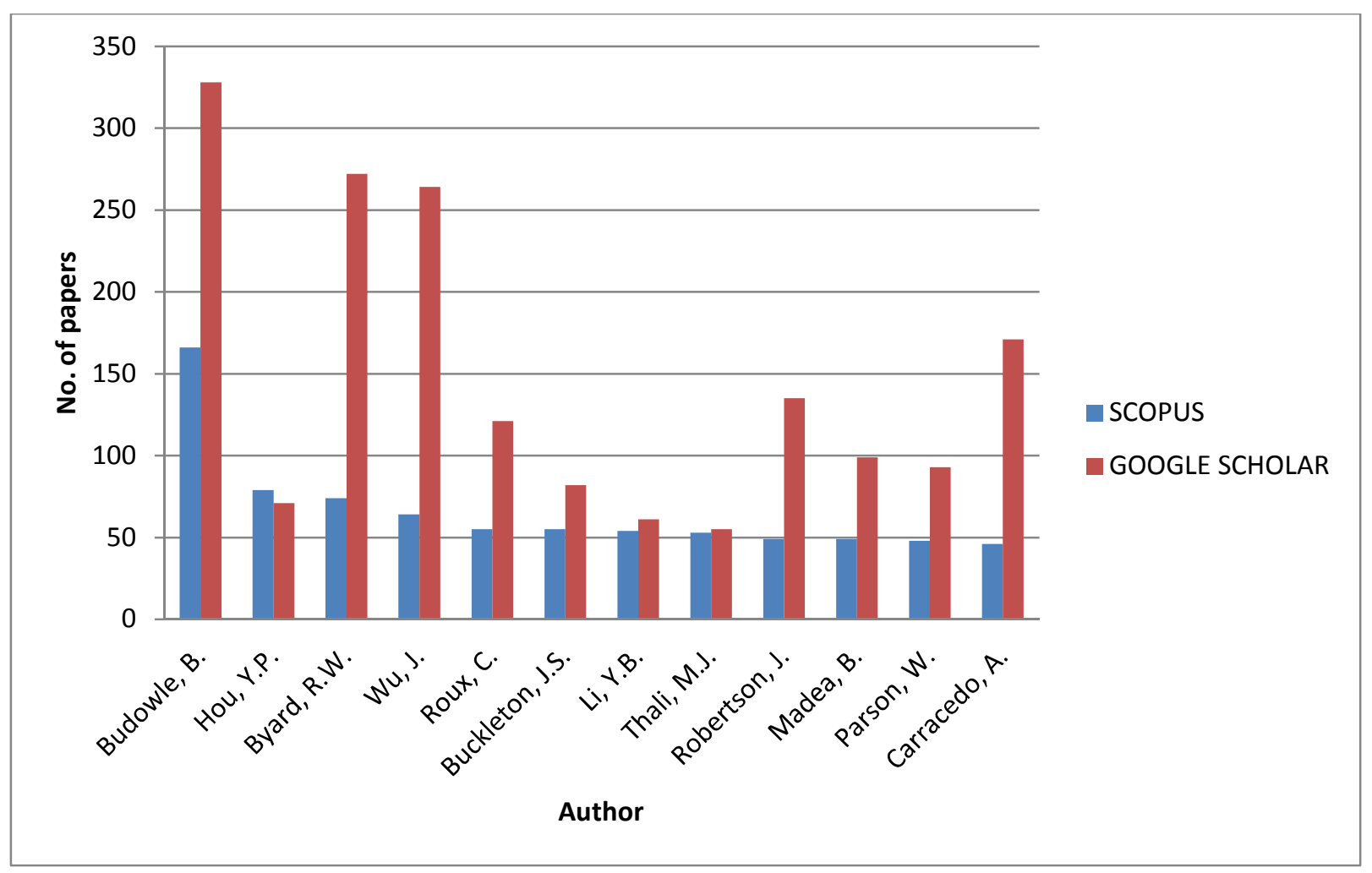

Fig 3: Comparison of SCOPUS and Google Scholar 


\section{Authors' Impact}

The impact of the twelve authors discussed in the preceding paragraph is analysed using Harzing's Publish or Perish Software. Publish or Perish is a software program that retrieves and analyses academic citations. It uses Google Scholar to obtain the raw citations, then analyses these and presents the total number of papers, total citations, h-index, g-index, etc. Google Scholar generally provides a higher citation count than the WOS or SCOPUS databases because it includes citations from all academic publications regardless of where they appeared. Hence, Google Scholar provides a more comprehensive picture of recent impact. The details of authors' impact are given in Table 3.

Table 3: Authors' impact

\begin{tabular}{|l|r|r|r|r|r|}
\hline Author & \multicolumn{1}{|l|}{ Papers } & Citations & h-index & g-index & e-index \\
\hline Budowle, B & 328 & 10155 & 52 & 89 & 62.96 \\
\hline Hou, Y.P & 71 & 293 & 6 & 15 & 13.6 \\
\hline Byard, R.W & 272 & 3692 & 26 & 45 & 30.79 \\
\hline Wu, J & 264 & 1273 & 19 & 30 & 19.54 \\
\hline Roux, C & 121 & 1427 & 22 & 32 & 20.22 \\
\hline Buckleton, J. S & 82 & 1388 & 20 & 34 & 23.15 \\
\hline Li, Y.B & 61 & 267 & 5 & 15 & 13.45 \\
\hline Thali, M.J & 55 & 1419 & 25 & 36 & 24.02 \\
\hline Robertson, J & 135 & 2336 & 24 & 45 & 33.88 \\
\hline Madea, B & 99 & 1513 & 24 & 34 & 21.26 \\
\hline Parson, W & 93 & 3163 & 26 & 54 & 42.31 \\
\hline Carracedo, A & 171 & 4127 & 32 & 59 & 44.06 \\
\hline
\end{tabular}

Bruce Budowle is not only a highly productive author in terms of contribution but also the high impact author with very high citation records and also an impressive h-index. During the period of study he has received 10155 citations. His h-index is 52 , a clear high among his peers. The next highest is $\mathrm{A}$. Carracedo with 4127 citations and h-index of 32. 


\section{Most Cited Papers}

The top ten most cited papers obtained from SCOPUS is listed in Table 4. A paper entitled "Genetic variation at five trimetric and tetrametric tandem repeat loci in four human population groups" by

Edwards A., et al. published in the journal Genomics in the year 1992 has received the highest citation count 817. Further, from titles it is inferred that seven out of the top ten papers belong to DNA Technology. This shows that more research activities are being carried on in newly developing fields.

\begin{tabular}{|c|c|c|c|c|}
\hline Authors & Title & Year & Source title & $\begin{array}{l}\text { Cited } \\
\text { by }\end{array}$ \\
\hline Edwards A., et al. & $\begin{array}{l}\text { Genetic variation at five trimeric and } \\
\text { tetrameric tandem repeat loci in four } \\
\text { human population groups }\end{array}$ & 1992 & Genomics & 817 \\
\hline Kress W.J., et al. & $\begin{array}{l}\text { Use of DNA barcodes to identify } \\
\text { flowering plants }\end{array}$ & 2005 & $\begin{array}{l}\text { Proceedings of the } \\
\text { National Academy } \\
\text { of Sciences of the } \\
\text { United States of } \\
\text { America }\end{array}$ & 404 \\
\hline $\begin{array}{l}\text { Jobling M.A., et } \\
\text { al. }\end{array}$ & $\begin{array}{l}\text { The human Y chromosome: An } \\
\text { evolutionary marker comes of age }\end{array}$ & 2003 & $\begin{array}{l}\text { Nature Reviews } \\
\text { Genetics }\end{array}$ & 360 \\
\hline $\begin{array}{l}\text { Lindoln P., } \\
\text { Carracedo A. }\end{array}$ & $\begin{array}{l}\text { Publication of population data of human } \\
\text { polymorphisms }\end{array}$ & 2000 & $\begin{array}{l}\text { Forensic Science } \\
\text { International }\end{array}$ & 354 \\
\hline $\begin{array}{l}\text { Takats Z., } \\
\text { Wiseman J.M., } \\
\text { Cooks R.G. }\end{array}$ & $\begin{array}{l}\text { Ambient mass spectrometry using } \\
\text { desorption electrospray ionization } \\
\text { (DESI): Instrumentation, mechanisms } \\
\text { and applications in forensics, chemistry, } \\
\text { and biology }\end{array}$ & 2005 & $\begin{array}{l}\text { Journal of Mass } \\
\text { Spectrometry }\end{array}$ & 264 \\
\hline Kayser M., et al. & $\begin{array}{l}\text { Characteristics and frequency of } \\
\text { germline mutations at microsatellite loci } \\
\text { from the human Y chromosome, as } \\
\text { revealed by direct observation in } \\
\text { father/son pairs }\end{array}$ & 2000 & $\begin{array}{l}\text { American Journal of } \\
\text { Human Genetics }\end{array}$ & 232 \\
\hline Thali M.J., et al & $\begin{array}{l}\text { Virtopsy, a new imaging horizon in } \\
\text { forensic pathology: Virtual autopsy by } \\
\text { postmortem multislice computed } \\
\text { tomography (MSCT) and magnetic } \\
\text { resonance imaging (MRI) - A feasibility } \\
\text { study }\end{array}$ & 2003 & $\begin{array}{l}\text { Journal of Forensic } \\
\text { Sciences }\end{array}$ & 231 \\
\hline Gill P., et al. & $\begin{array}{l}\text { An investigation of the rigor of } \\
\text { interpretation rules for STRs derived } \\
\text { from less than } 100 \text { pg of DNA }\end{array}$ & 2000 & $\begin{array}{l}\text { Forensic Science } \\
\text { International }\end{array}$ & 220 \\
\hline Novembre J., et & Genes mirror geography within Europe & 2008 & Nature & 219 \\
\hline
\end{tabular}




\begin{tabular}{|l|l|r|l|c|}
\hline al. & & & \\
\hline Jain A.K., Ross A., & Biometrics: A tool for information \\
Pankanti S. & security & 2006 & $\begin{array}{l}\text { IEEE Transactions } \\
\text { on Information } \\
\text { Forensics and } \\
\text { Security }\end{array}$ & 212 \\
\hline
\end{tabular}

\section{Ranked List of Source Journals}

The source journals are ranked based on the number of articles contributed. The list is given in Table 5.

Table 5: Top ranking source journals

\begin{tabular}{|l|l|l|l|}
\hline Rank & Journal & No. of articles & $\begin{array}{l}\text { Percentage } \\
\text { of 13626 }\end{array}$ \\
\hline 1 & Journal of Forensic Science & 4497 & 33.00 \\
\hline 2 & Forensic Science International & 1544 & 11.33 \\
\hline 3 & Science \& Justice (Journal of Forensic Science Society) & 718 & 5.27 \\
\hline 4 & Z Zagadnien Nauk Sadowych & 169 & 1.24 \\
\hline 5 & Legal Medicine & 167 & 1.23 \\
\hline 6 & American Journal of Forensic Pathology & 145 & 1.06 \\
\hline 7 & International Journal of Legal Medicine & 136 & 1.00 \\
\hline 8 & Journal of the Canadian Society of Forensic Science & 127 & 0.93 \\
\hline 9 & Australian Journal of Forensic Science & 126 & 0.92 \\
\hline 10 & Journal of Forensic Identification & 102 & 0.75 \\
\hline & Total & 7731 & 56.73 \\
\hline
\end{tabular}

Journal of Forensic Sciences with 4497 articles i.e., 33\% of the total contribution is the top most source journal. This is followed by Forensic Science International with $11.33 \%$ percent of the total contribution (1544 articles). Science \& Justice with a contribution of 5.27\% (718 articles) is the third ranked journal. These three journals together contribute approximately half $(49.6 \%)$ of the total literature output. Apart from these core forensic science journals, general science periodicals like Nature (67 articles) and Science (54 articles) have also contributed to the total forensic science literary output. Similarly, scientific journals of other fields like Proceedings of SPIE (81 articles), Analytical Chemistry (56 articles), Journal of Chromatography $A$ (54 articles) have contributed to forensic science literature. Since forensic 
science is a multi-disciplinary subject forensic science literature does not pertain only to core forensic science journals but can also found in peripheral, related and general science journals.

\section{Country-wise Contributions}

Twenty one countries have contributed more than 100 articles during the period of study. These countries and the percentage of their contribution are listed in Table 6.

Table 6: Country-wise contribution

\begin{tabular}{|c|c|c|c|}
\hline Rank & Country & Contribution & $\begin{array}{r}\text { Percentage } \\
\text { of } 13626\end{array}$ \\
\hline 1 & United States & 4197 & 30.80 \\
\hline 2 & United Kingdom & 1511 & 11.10 \\
\hline 3 & Germany & 789 & 5.79 \\
\hline 4 & Australia & 672 & 4.93 \\
\hline 5 & Japan & 581 & 4.26 \\
\hline 6 & Canada & 577 & 4.23 \\
\hline 7 & China & 511 & 3.75 \\
\hline 8 & India & 414 & 3.04 \\
\hline 9 & Italy & 394 & 2.90 \\
\hline 10 & France & 370 & 2.72 \\
\hline 11 & Switzerland & 339 & 2.49 \\
\hline 12 & Spain & 279 & 2.05 \\
\hline 13 & Poland & 194 & 1.42 \\
\hline 14 & Netherlands & 184 & 1.35 \\
\hline 15 & Sweden & 177 & 1.30 \\
\hline 16 & New Zealand & 169 & 1.24 \\
\hline 17 & Turkey & 164 & 1.20 \\
\hline 18 & Israel & 153 & 1.12 \\
\hline 19 & Austria & 144 & 1.06 \\
\hline 20 & Brazil & 127 & 0.93 \\
\hline \multirow[t]{2}{*}{21} & Belgium & 120 & 0.88 \\
\hline & Total & 12066 & 88.56 \\
\hline
\end{tabular}

The United States of America has contributed 4197 articles (30.80\% of the total contributions). The United Kingdom is ranked second in terms of total contribution to the forensic science literature during 
the period of study. It has contributed a total of 1511 articles, which is $11.10 \%$ of the total contribution. These two countries together have contributed $41.9 \%$ of the total forensic science literature output.

\section{Affiliating Institution}

Table 7 shows the ten top ranking Institutions of the world in terms of the number of contribution in forensic science literature.

Table 7: Affiliating institution-wise contribution

\begin{tabular}{|l|l|r|r|}
\hline Rank & Affiliation & Contribution & Percentage of 13626 \\
\hline 1 & Forensic science Service, Birmingham & 196 & 1.44 \\
\hline 2 & The FBI Academy & 142 & 1.04 \\
\hline 3 & Universität Lausanne Schweiz & 132 & 0.97 \\
\hline 4 & Sichuan University & 125 & 0.92 \\
\hline 5 & Forensic science Centre, Adelaide & 97 & 0.71 \\
\hline 6 & FBI Laboratory & 93 & 0.68 \\
\hline 7 & National Research Institute of Police Science & 90 & 0.66 \\
\hline 7 & University of Strathclyde & 90 & 0.66 \\
\hline 8 & Netherlands Forensic Institute & 85 & 0.62 \\
\hline 9 & University of Adelaide & 83 & 0.60 \\
\hline 9 & Institute of Forensic Research & 83 & 0.60 \\
\hline 10 & Michigan State University & 80 & 0.59 \\
\hline & Total & 1296 & 9.49 \\
\hline
\end{tabular}

Forensic Science Service, Birmingham is the highest contributor with 196 articles (1.44\%) followed by FBI Academy with 142 articles (1.04\%). Except for the sixth ranked FBI Laboratory, all other institutions are either research institutions or educational institutions. The policy of not giving incentives for research publications might be the contributing factor for less scientific productivity among the forensic scientists, as most of them are working in government controlled laboratories (Jones, 1998). Cash incentives, promotions and higher status may give an impetus to research in the government controlled laboratory set-up. This can help in the growth of research publications output and also the impact factor of journals as well as the authors. 


\section{CONCLUSION}

Forensic science literature has doubled in a period of ten years confirming the statement of Derek de Solla Price. Bruce Budowle is the author who has contributed the highest number of articles. He has received the most number of citations during the period of study and his h-index obtained from Google Scholar is as high as 52. Journal of Forensic Sciences is the top ranking source journal. It contributes 33\% of the total forensic science literature during the period of study. The three journals, Journal of Forensic Sciences, Forensic Science International and Science \& Justice contribute almost half of the total forensic science literature. Forensic science literature is found scattered not only in the core journals but also in the journals of other allied subjects. The United States of America has contributed the maximum number of articles. The United Kingdom is the second high productive country. Rest of the world contributes only about $58 \%$ of forensic science literature. Most of the contributions come from the educational and research institutions. The FBI Laboratory is the only forensic science laboratory in the top ten contributors. Cash incentives, promotions and higher status may go a long way in promoting research in the government controlled laboratory set-up.

\section{References}

1. Harzing, A.W. 2007. Publish or Perish, available from http://www.harzing.com/pop.htm

2. Harzing, A.W. 2008. Google scholar - A new data source for citation analysis, available from http://www.harzing.com/pop.htm

3. Holt, C. 2006. Guide to Information Sources in the Forensic science. Connecticut: Libraries Unlimited. 
4. Jeyasekar, J.J. and Saravanan, P. 2012. Scientometric analysis of forensic science publications: A study based on SCOPUS database. Proceedings of the UGC-SAP National Seminar on Scientometrics and Informetrics. Annamalai Nagar, India: Annamalai University: 75-78.

5. Jeyasekar, J.J. and Saravanan, P. 2012. Scientometric analysis of Indian forensic science literature based on ICl database. Journal of Library Advancements, Vol.2, No.1: 1-4.

6. Jeyasekar, J.J. and Saravanan, P. 2013. Journal of forensic sciences: A bibliometric study for the period 2006 to 2010. Paper presented in the Second National Conference on Scientometrics and Knowledge Management, April, 2013. Dharwad, India.

7. Jones, A.W. 1998. Citation trends and practices in the Journal of Forensic Sciences as documented by ISI's Journal Citation Report. Journal of Forensic Sciences, Vol.43, No.2: 439-444.

8. Jones, A.W. 2003 Impact factors of forensic science and toxicology journals: What do the numbers really mean. Forensic Science International, Vol. 133, No.1: 1-8.

9. Jones, A.W. 2005. Which articles and which topics in the forensic sciences are most highly cited? Science \& Justice, Vol.45, No.3: 175-182.

10. Jones, A.W. 2007. The distribution of forensic science journals, reflections on authorship practices, peer-review and the role of the impact factor. Forensic Science International, Vol. 165, No.2: 115-128.

11. Nalimov, V.V. and Mulechenko, Z.M. 1969. Naukometriya Izuchenie Razvitiya Nauki kak Informatsionnogo Protsessa. [Scientometrics study of the development of science as an information process]. Moscow: Nauka. (English translation: 1971. Washington, D.C.: Foreign Technology Division. U.S. Air Force Systems Command, WrightPatterson AFB, Ohio. (NTIS Report No. AD735634)) cited by: Wilson, C S (1999). Informetrics. Annual Review of Information Science and Technology. Vol.34: 107-247.

12. Price, D de Solla. 1963. Little Science, Big Science. New York: Columbia University Press. 
13. Saferstein, R. 2001. Criminalistics: An Introduction to Forensic Science. $7^{\text {th }}$ ed., New Jersey: Prentice-Hall.

14. Sauvageau, A; Desnoyers, S and Godin, A. 2009. Mapping the Literature in Forensic science: A Bibliometric Study of North-American Journals from 1980 to 2005. The Open Forensic Science Journal, 2: 41-46.

15. Tague-Sutcliffe, J. 1992. An introduction to informetrics. Information Processing and Management. Vol. 28, No. 1: 13.

16. Wilson, C.S. 1999. Informetrics. Annual Review of Information Science and Technology. Vol.34: 107-247. 